\title{
Strategi Pengembangan Kompetensi Pustakawan di Dinas Perpustakaan dan Kearsipan Kabupaten Gunung Kidul
}

\author{
Nur Istikomah ${ }^{1}$, Anis Masruri ${ }^{2}$ \\ Program Studi Ilmu Perpustakaan, Fakultas Adab dan Ilmu Budaya \\ UIN Sunan Kalijaga Yogyakarta Yogyakarta \\ nuristikomah1717@gmail.com
}

\begin{abstract}
Introduction. This study aims to determine the strategy of developing the competence of librarians at the Office of the Dinas Perpustakaan dan Kearsipan Kabupaten Gunung Kidul.

Data Collection Method. This research uses descriptive qualitative method. Methods of data collection using frank or covert observation, semi-structured interviews, and documentation. The technique of determining the informants used purposive sampling. The data analysis technique in this study uses the theory of Miles and Hubermen, namely data reduction, data presentation, and drawing conclusions. Test the validity of the data in this study using a credibility test which includes: extension of observation, triangulation, and member check. Transferability test, depenability test, and confirmability test.

Result and Discussions. The research results are; (1) The librarian competency development strategy is divided into two, namely formal and informal development. Formal development is in the form of: training, technical guidance, workshops, seminars, professional organizations, competitions for outstanding librarians and fostered areas for librarians. Meanwhile, informal librarian competency development includes: being a resource person or speaker, coordinating fellow librarians, networking, and relationships. (2) supporting factors in the implementation of librarian competency development include: motivation within the librarian itself and full support from the service and the head of the Dinas Perpustakaan dan Kearsipan Kabupaten Gunung Kidul Service. While the inhibiting factors that need special attention are related to the budget for developing the competence of librarians and limiting quotas in an activity.

Conclusions. The suggestion to be given for the strategy of developing the competence of librarians at the Office of the Dinas Perpustakaan dan Kearsipan Kabupaten Gunung Kidul is to maximize the available budget for developing the competence of librarians by being more selective in choosing the development activities to be carried out. And for librarians who have the opportunity to take part in training activities, seminars, workshops, technical guidance and other competency development, they can share their knowledge and knowledge with other librarians.
\end{abstract}

Keywords: Strategy, Development, Librarian Competence

\section{ABSTRAK}

Pendahuluan. Penelitian ini bertujuan untuk mengetahui strategi pengembangan kompetensi pustakawan di Dinas Perpustakaan dan Kearsipan Kabupaten Gunung Kidul.

Metode Penelitian. Penelitian ini menggunakan jenis penelitian deskriptif kualitatif. Metode pengumpulan data menggunakan observasi terus terang atau tersamar, wawancara semiterstruktur, dan dokumentasi. Teknik penentuan informan menggunakan pusposive sampling. Teknik analisis data dalam penelitian ini menggunakan teori Miles dan Hubermen, yaitu reduksi data, penyajian data, dan penarikan kesimpuan. Uji keabsahan data dalam penelitian ini 
menggunakan uji kredibilitas yang meliputi: perpanjangan pengamatan, triangulasi, dan membercheck. Uji transferability, uji depenability, dan uji confirmability.

Hasil Pembahasan. Hasil penelitian yaitu; (1) Strategi pengembangan kompetensi pustakawan dibagi menjadi dua yaitu pengembangan secara formal dan informal. Pengembangan secara formal berupa: diklat, bimtek, worksop, seminar, organisasi profesi, lomba pustakawan berprestasi dan wilayah binaan untuk pustakawan. Sedangkan pengembangan kompetensi pustakawan secara informal meliputi : menjadi narasumber atau pembicara, koordinasi sesama pustakawan, networking, dan relationship. (2) faktor pendukung dalam pelaksanaan pengembangan kompetensi pustakawan diantaranya: motivasi dalam diri pustakawan itu sendiri serta dukungan penuh dari pihak dinas dan Kepala Dinas Perpustakaan dan Kearsipan Kabupaten Gunung Kidul. Sedangkan faktor penghambat yang perlu menjadi perhatian khusus yakni terkait dengan anggaran dana untuk pengembangan kompetensi pustakawan dan pembatasan kuota dalam sebuah kegiatan.

Kesimpulan dan Saran. Saran yang ingin diberikan untuk strategi pengembangan kompetensi pustakawan Dinas Perpustakaan dan Kearsipan Kabupaten Gunung Kidul ialah memaksimalkan anggaran yang dimiliki untuk pengembangan kompetensi pustakawan dengan lebih selektif memilih kegiatan pengembangan yang akan dilakukan. Serta bagi pustakawan yang berkesempatan mengikuti kegiatan diklat, seminar, workshop, bimbingan teknis maupun pengembangan kompetensi lainnya dapat sharing mengenai ilmu dan pengetahuan yang didapatkan kepada pustakwan yang lain.

Kata Kunci : Strategi, Pengembangan, Kompetensi Pustakawan

\section{PENDAHULUAN}

Undang-Undang Nomor 43 Tahun 2007 menjelaskan bahwa perpustakaan merupakan institusi pengelola informasi yang memiliki fungsi sebagai tempat pendidikan, penelitian, pelestarian, informasi dan rekreasi. Perpustakaan bertujuan untuk memberikan layanan kepada pemustaka, meningkatkan kegemaran membaca, serta memperluas wawasan dan pengetahuan untuk mencerdaskan kehidupan bangsa dengan penyelenggaraan berdasarkan asas pembelajaran sepanjang hayat (long life education).

Standar Kompetensi Kerja Nasional Indonesia (SKKNI) menyebutkan bahwa kompetensi adalah pernyataan tentang bagaimana seseorang dapat mendemonstrasikan: keterampilan, pengetahuan, dan sikapnya ditempat kerja sesuai standar industri atau sesuai dengan persyaratan yang ditetapkan oleh tempat kerja. Pustakawan sebagai profesi sekurang-kurangnya harus memiliki kompetensi profesional dan kompetensi personal. Kompetensi profesional mencakup penguasaan ilmu pengetahuan, keahlian, 
dan sikap kerja. Kompetensi personal mencakup aspek kepribadian dan interaksi sosial (Pasal 34 Peraturan Pemerintah No 24 Tahun 2014).

Pustakawan memiliki peran yang strategis dalam pengembangan perpustakaan, sebab pustakawan merupakan inti dari seluruh sistem yang dirancang, metode yang diterapkan, dan teknologi yang digunakan. Oleh karena itu, menjadi penting untuk mengembangkan pustakawan. Pustakawan harus dikembangkan dan ditingkatkan kompetensinya guna meningkatkan produktivitas dan kinerja pustakawan. Kinerja merupakan pencapaian pelaksanaan suatu kegiatan perencanaan strategis dan operasional organisasi, lembaga, maupun perpustakaan oleh seseorang atau kelompok secara kuantitas maupun kualitas sesuai tugas, kewajiban dan tanggung jawab yang tidak melanggar ketentuan hukum, etika, dan moral. Kinerja merefleksikan seberapa baik pustakawan memenuhi persyaratan sebuah pekerjaan (Lasa, 2017: 179). Pengembangan kompetensi mensyaratkan bahwa pustakawan wajib meningkatkan pengetahuan dan keterampilannya sehingga memberikan hasil dan mutu kerja yang berbobot.

Masalah pengembangan kompetensi pustakawan menjadi sebuah tantangan mengingat realitas waktu yang dimiliki pustakawan habis tersita untuk mengerjakan pekerjaan rutinnya, sehingga kurang memiliki waktu untuk mengembangkan kemampuan diri dan kurang dalam penguasaan teknologi informasi. Selain itu, pustakawan sering terjebak dalam zona nyaman dalam kemauan diri untuk mengembangkan kompetensi dan merasa puas dengan apa yang sudah dilakukannya selama ini. Sedangkan, untuk mendukung terciptanya layanan prima dan sesuai dengan tuntutan kebutuhan pengguna menjadi tantangan tersendiri untuk pustakawan yang harus diatasi melalui manajemen perpustakaan yang dikelola secara profesional.

Berdasarkan penjelasan Bapak Drs. Ali Ridlo, M.M selaku kepala, Dinas Perpustakaan dan Kearsipan Kabupaten Gunung Kidul mengelola berbagai jenis koleksi dan melayani pengguna serta sudah menerapkan teknologi informasi dalam pelaksanaannya. Perpustakaan tidak hanya menyediakan layanan tempat untuk membaca buku tetapi juga mengadakan program transformasi perpustakaan berbasis inklusi sosial atau tempat berkegiatan masyarakat yang dapat meningkatkan taraf hidup 
(Wawancara, 29 Juli 2020). Dalam melakukan pelayanan tersebut, tentunya perpustakaan menginginkan pelayanan yang terbaik bagi pemustaka. Untuk menghasilkan pelayanan yang baik salah satu faktor pendukungnya adalah memiliki pustakawan yang kompeten. Dinas Perpustakaan dan Kerasipan Kabupaten Gunung Kidul berupaya meningkatkan kompetensi pustakawan untuk meningkatkan kualitas layanan serta menjawab kebutuhan dari para pengguna perpustakaan. Dengan permasalahan tersebut, peneliti tertarik untuk melakukan penelitian dengan judul "Strategi Pengembangan Kompetensi Pustakawan di Dinas Perpustakaan dan Kearsipan Kabupaten Gunung Kidul.”

\section{TINJAUAN PUSTAKA}

\section{Pengertian Strategi}

Strategi adalah rencana aksi global yang menggambarkan alokasi sumber daya dan aktivitas lainnya untuk menghadapi lingkungan dan menolong organisasi mencapai tujuan tertingginya (Safaria, 2004: 99).

Berdasarkan definisi di atas dapat disimpulkan bahwa strategi merupakan suatu pola yang telah direncanakan dalam proses kegiatan guna mewujudkan tujuan.

\section{Pengertian Pengembangan}

Pengembangan adalah proses, cara, perbuatan mengembangkan. Pengembangan menurut Undang-Undang Republik Indonesia Nomor 18 Tahun 2002 adalah kegiatan ilmu pengetahuan dan teknologi yang bertujuan memanfaatkan kaidah dan teori ilmu pengetahuan yang telah terbukti kebenarannya untuk meningkatkan fungsi, manfaat, dan aplikasi ilmu pengetahuan dan teknologi yang telah ada, atau menghasilkan teknologi baru (Badan Pengembangan dan Pembinaan Bahasa, 2018: 788).

\section{Pengertian Perpustakaan}

Perpustakaan adalah suatu institusi yang di dalamnya tercakup unsur koleksi (informasi), pengolahan, penyimpanan, dan pemakai. Secara sederhana, perpustakaan juga dapat dinyatakan sebagai unit kerja yang memiliki sumber daya manusia "ruang khusus”, dan kumpulan koleksi sesuai dengan jenis perpustakaan (Qalyubi dkk, 2007:3). 


\section{Pengertian Pustakawan}

Pustakawan adalah seorang tenaga kerja bidang perpustakaan yang telah memiliki pendidikan ilmu perpustakaan, baik melalui pelatihan, kursus, seminar, maupun pendidikan formal (Suwarno, 2011: 33).

\section{Kompetensi Pustakawan}

Pustakawan harus memiliki enam jenis kompetensi sebagai berikut:

a. Kompetensi Profesional

Kompetensi ini mencakup aspek pengetahuan, keahlian, dan sikap kerja. Yakni kemampuan pustakawan untuk menguasai sumber-sumber informasi, teknologi informasi, manajemen, penelitian, dan mampu menggunakan pengetahuan tersebut untuk menyelenggarakan layanan profesional.

b. Kompetensi Personal

Kompetensi individu yang meliputi aspek kepribadian dan interaksi sosial. Yaitu mampu menjadi komunikator yang baik, meningkatkan pengetahuan, mampu berprestasi secara optimal, mengikuti perkembangan bidang kepustakawanan, dan kemampuan bekerjasama untuk menciptakan nilai lebih dari penyelenggaraan kepustakawanan.

c. Kompetensi Informasi

Kompetensi informasi adalah kemampuan dan ketrampilan mencari, mengumpulkan, mengintegrasikan, dan menggunakan informasi berdasarkan situs sosial tertentu. Kompetensi informasi meliputi aspek-aspek keberaksaraan informasi, literasi informasi, literasi jaringan, dan literasi media serta literasi digital.

d. Kompetensi Komunikasi

Pustakawan sebagai individu dan profesional dituntut untuk menguasai kompetensi komunikasi organisasi, komunikasi interpersonal, komunikasi intrapersonal, komunikasi kelompok, dan komunikasi massa.

e. Kompetensi Sosial

Kompetensi sosial adalah kemampuan berinteraksi secara baik dengan orang lain, berusaha memberi yang terbaik kepada sebanyak-banyak orang, ramah, empati, menolong, dan memberi senyum. 
f. Kompetensi Manajerial

Kompetensi manajerial adalah penguasaan pengetahuan, keahlian, dan sikap manajemen meliputi :

a) Visi, misi, tujuan, dan perencanaan sumber daya manusia, sistem, gedung/tata ruang, anggaran, koleksi, dan pemberdayaan perpustakaan.

b) Koordinasi kegiatan perpustakaan seperti pengolahan, penjajaran, penyimpanan, dan penyediaan jasa informasi.

c) Bentuk-bentuk pengawasan yang efektif.

d) Memahami bentuk-bentuk kerja sama dengan pihak lain (Lasa, 2017: 110).

\section{Pengembangan Kompetensi Pustakawan}

Hasibuan dalam Kadarisman mengemukakan bahwa pengembangan sumber daya manusia dibagi menjadi dua jenis :

a) Pengembangan Formal

Pengembangan secara formal yaitu sumber daya manusia yang dimiliki ditugaskan oleh organisasi untuk mengikuti pendidikan atau pelatihan, baik yang dilakukan organisasi maupun yang dilaksanakan oleh lembaga-lembaga pendidikan atau pelatihan.

b) Pengembangan Informal

Pengembangan secara informal yaitu sumber daya manusia atau pustakawan atas keinginan dan usaha sendiri melatih dan mengembangkan dirinya dengan mempelajari buku-buku literatur yang ada hubungannya dengan pekerjaan atau jabatannya (Kadarisman, 2013: 29).

\section{METODOLOGI PENELITIAN}

Penelitian ini menggunakan metode penelitian deskriptif kualitatif. Penelitian kualitatif adalah metode penelitian yang berlandaskan pada filsafat postpositivisme, digunakan untuk meneliti pada kondisi obyek yang alamiah, (sebagai lawannya adalah eksperimen) dimana peneliti adalah sebagai instrumen kunci, teknik pengumpulan data dilakukan menggunakan triangulasi (gabungan), analisis data bersifat induktif atau kualitatif, dan hasil penelitian lebih menekankan makna dari pada generalisasi (Sugiyono, 2018; 9). Subjek dalam 
penelitian ini adalah Dinas Perpustakaan dan Kearsipan Kabupaten Gunung Kidul Yogyakarta dan objek dalam penelitian ini adalah Strategi Pengembangan Kompetensi Pustakawan di Dinas Perpustakaan dan Kearsipan Kabupaten Gunung Kidul Yogyakarta. Metode pengumpulan data menggunakan observasi terus terang atau tersamar, wawancara semiterstruktur, dan dokumentasi. Teknik penentuan informan menggunakan pusposive sampling. Teknik analisis data dalam penelitian ini menggunakan teori Miles dan Hubermen , yaitu reduksi data, penyajian data, dan penarikan kesimpuan. Uji keabsahan data dalam penelitian ini menggunakan uji kredibilitas yang meliputi: perpanjangan pengamatan, triangulasi, dan membercheck. Uji transferability, uji depenability, dan uji confirmability.

\section{HASIL DAN PEMBAHASAN}

1. Strategi Pengembangan Kompetensi Pustakawan di Dinas Perpustakaan dan Kearsipan Kabupaten Gunung Kidul

1. Pengembangan Formal
a. Diklat

Pengembangan kompetensi pustakawan di Dinas Perpustakaan dan Kearsipan Kabupaten Gunung Kidul salah satunya diikutsertakan dalam diklat yang dilaksanakan oleh Pusdiklat Perpustakaan Nasional RI. Pusdiklat Perpustakaan Nasional RI merencanakan dan mengembangkan kurikulum yang sesuai dan dibutuhkan oleh pustakawan yaitu diklat fungsional bidang kepustakawanan dan diklat teknis bidang kepustakawanan. Pustakawan yang diangkat melalui jalur inpassing yang tidak memiliki latar belakang pendidikan ilmu perpustakaan diwajibkan mengikuti diklat teknis pengelolaan perpustakaan sebagai syarat agar tetap dapat jabatan fungsional pustakawannya.

b. Bimtek, Workshop, dan Seminar.

Pengembangan kompetensi pustakawan selanjutnya yaitu mengikutsertakan pustakawan dalam kegiatan workshop, seminar dan bimtek. Contoh pengembangan pustakawan di Dinas Perpustakaan dan Kearsipan Kabupaten Gunung Kidul yang pertama, adalah bimbingan teknis atau disingkat bimtek. Bimtek adalah suatu 
pelatihan yang diberikan kepada pustakawan guna meningkatkan kompetensi teknis untuk membantu menyelesaikan tugas pekerjaan. Yang kedua adalah workshop, contoh workshop di lingkungan Dinas adalah pembelajaran penulisan. Dalam upaya meningkatkan budaya membaca dan menulis di Lingkungan Aparatur Sipil Negara serta mendorong para ASN untuk bisa meningkatkan kompetensi kepenulisannya. Yang Ketiga yakni seminar, kegiatan seminar yang bertujuan untuk mengembangkan kompetensi pustakawan bisa dilakukan secara personal maupun diikutsertakan oleh Dinas Perpustakaan dan Kearsipan Kabupaten Gunung Kidul. Terlebih saat masa pandemi ini banyak kegiatan seminar yang dilakukan secara daring atau biasa disebut sebagai webinar, sehingga pustakawan dapat mengikuti kegiatan seminar dengan mudah. Dalam meningkatkan kompetensi melalui seminar, pustakawan dapat mengikuti seminar-seminar secara mandiri sebagai wujud keinginan untuk meningkatkan pengetahuan dan ketrampilan yang dimiliki.

c. Organisasi Profesi

Dinas Perpustakaan dan Kearsipan Kabupaten Gunung Kidul selama ini selalu mendampingi tumbuh dan gerak organisasi literasi di Kabupaten Gunung Kidul seperti Ikatan Pustakawan Indonesia (IPI), Gerakan Pemasyarakatan Minat Baca (GPMB), Forum Penulis Negeri Batu (FPMB) dan komunitas literasi lainnya di Kabupaten Gunung Kidul. Memberikan dukungan berupa SDM yang terdiri dari para pustakawan dan aparatur di lingkungan Dispussip untuk bersama bergabung menguatkan kapasitas kepengurusan. Organisasi profesi dapat menunjang kualitas sumber daya manusia dalam profesi pustakawan. Organisasi profesi dibentuk untuk mengarahkan pustakawan dalam mengelola perpustakaan dengan baik, penyedia informasi sesuai dengan kebutuhan pemakai, dan mengembangkan ilmu perpustakaan yang dimiliki oleh pustakawan. Organisasi profesi dapat menekankan pada pengembangan bidang, menambah kualitas anggota, meningkatkan kesejahteraan anggota, dan mengarahkan profesionalisme anggota. 
d. Lomba Pustakawan Berprestasi

Upaya Dinas Perpustakaan dan Kearsipan Kabupaten Gunung Kidul dalam meningkatkan kompetensi dan mengembangkan profesionalisme pustakawan secara sistematis dan berkelanjutan, salah satunya dengan mengikutsertakan pustakawan dalam pemilihan pustakawan berprestasi. Pemilihan pustakawan berprestasi merupakan kompetisi tahunan yang diselenggarakan oleh Perpustakaan Nasional Republik Indonesia. Seleksi dilakukan di tingkat provinsi di mana juara pertama dari setiap provinsi akan dikirimkan untuk pemilihan tingkat nasional.

e. Wilayah Binaan

Selain hal tersebut di atas, strategi pengembangan kompetensi pustakawan secara formal yang dilakukan Dinas Perpustakaan dan Kearsipan Kabupaten Gunung Kidul adalah memberikan wilayah binaan kepada para pustakawan. Pustakawan yang ada di Dinas diberi tugas membina wilayah-wilayah yang tersebar di 18 kecamatan, Kabupaten Gunung Kidul. Pembinaan tersebut berkonsentrasi pada perpustakaan desa dan perpustakaan SD, SMP di masing-masing wilayah kecamatan. Kegiatan pembinaan berupa pendampingan terhadap perpustakaan desa maupun perpustakaan sekolah, pendampingan akreditasi, pelatihan komputer dan internet dasar untuk pengelola perpustakaan dan lain sebagainya (Wawancara, 2020). Untuk itu, pustakawan harus mampu mengembangkan kompetensi yang ada dalam dirinya guna mendukung aktivitas pembinaan tersebut. Sebagai pertanggung jawaban atas kinerjanya, pustakawan membuat laporan hasil kerja yang diberikan kepada Kepala Dinas Perpustakaan dan Kearsipan Kabupaten Gunung Kidul. Di sini kemampuan komunikasi, analisis, perencanaan, pengelolaan dan kemampuan lainnya akan terasah dengan tugas tersebut.

2. Pengembangan Informal

a. Menjadi Narasumber atau Pembicara

Salah satu kegiatan yang dilakukan oleh pustakawan Dinas Perpustakaan dan Kearsipan Kabupaten Gunung Kidul adalah memberikan pelatihan dan pengajaran. Kegiatan tersebut berupa bimbingan teknologi dan informasi, literasi informasi, cara 
memakai software aplikasi tertentu, serta menjadi pembicara atau narasumber dalam berbagai pertemuan ilmiah di bidang perpustakaan.

b. Koordinasi Sesama Pustakawan

Sebagai pustakawan yang mengelola perpustakaan dengan tugas kerja dan jangkauan yang luas, pustakawan harus bekerjasama dengan pustakawan lainnya. Sehingga saling bertukar informasi mutlak diperlukan. Dinas Perpustakaan dan Kearsipan Kabupaten Gunung Kidul juga melakukan pengembangan kompetensi melalui koordinasi sesama pustakawan.

c. Networking

Membangun kerjasama atau relasi dengan berbagai pihak menjadi bagian penting dalam dunia perpustakaan maupun kepustakawanan. Relasi atau kerjasama yang dilakukan dengan orang lain maupun organisasi dapat menghasilkan berbagai potensi dan informasi. Sering berdiskusi dengan banyak orang dapat memacu ide yang menghasilkan pengetahuan baru.

\section{d. Relationship}

Dalam upaya mengangkat profesionalitas pustakawan Dinas Perpustakaan dan Kearsipan Kabupaten Gunung Kidul kaitannya dengan kompetensi di era globalisasi informasi, keberadaan pustakawan yang terampil dalam pelayanan serta menguasai manajemen infromasi merupakan potensi yang perlu dikembangkan. Sehingga perpustakaan dapat memberikan pelayanan yang optimal dan memenuhi kebutuhan para pemustaka. Untuk mewujudkan profesionalitas pustakawan tersebut, dapat dilakukan dengan pendekatan psikologis. Karena peningkatan berbagai pengetahuan dan keterampilan pustakawan tidak cukup hanya melalui proses belajar melainkan harus disertai pengembangan diri oleh individu pustakawan itu sendiri. 


\section{Faktor yang Menghambat dan Mendukung Strategi Pengembangan} Kompetensi Pustakawan di Dinas Perpustakaan dan Kearsipan Kabupaten Gunung Kidul

1. Faktor Pendukung

a. Motivasi

Faktor pendukung dalam strategi pengembangan kompetensi Dinas Perputakaan dan Kearsipan Kabupaten Gunung Kidul adalah memiliki sumber daya manusia dengan semangat yang tinggi. Pustakawan harus terus meningkatkan dan mengembangkan diri mengikuti perkembangan teknologi guna memenuhi kebutuhan pemustaka. Jadi harus mau terus belajar dan memiliki pemikiranpemikiran untuk kemajuan perpustakaan. Semangat atau motivasi pustakawan sangat dibutuhkan untuk menimbulkan minat kerja. Dengan semangat motivasi yang tinggi di dalam diri pustakawan dapat memacu tumbuhnya potensi-potensi yang dimiliki guna meningkatkan kompetensi.

b. Dukungan Penuh

Dinas Perpustakaan dan Kearsipan Kabupaten Gunung Kidul memberikan dukungan penuh kepada para pustakawan untuk mengembangkanan kompetensi yang dimilikinya. Bentuk dukungan tersebut berupa kegiatan-kegiatan yang dilakukan Dinas guna mengembangkan kompetensi baik melalui diklat, pelatihan, workshop, dan seminar. Di sisi lain, Dinas memberikan kesempatan dan kelonggaran waktu selagi tidak menganggu penyelesaian tugas keja. Selain itu, tersedia anggaran khusus bagi para pustakawan yang dapat digunakan untuk mendukung kegiatan pengembangan kompetensi.

2. Faktor Penghambat

a. Keterbatasan Anggaran Dana

Anggaran dana merupakan salah satu faktor penting dalam mendukung operasional sebuah perpustakaan. Meskipun memiliki sumber daya manusia yang berkualitas, perpustakaan tidak dapat dikelola dan dioperasikan secara optimal tanpa anggaran dana yang mencukupi. 


\section{b. Pembatasan Kuota Peserta}

Adanya pembatasan kuota peserta dalam sebuah kegiatan menjadi salah satu faktor yang dapat menghambat pengembangan kompetensi pustakawan. Dengan adanya pembatasan kuota tersebut mengakibatkan tidak semua pustakawan bisa mengikuti kegiatan yang sedang dilaksanakan. Sebagai contoh, pelaksanan diklat biografi atau diklat akreditasi yang diselenggarakan oleh Perpustakaan Nasional Republik Indonesia (PERPUSNAS RI) dalam satu tahun hanya sekali dan dibatasi kuota peserta pada satu kali pelaksanaan diklat.

\section{KESIMPULAN}

Berdasarkan pembahasan yang telah dipaparkan sebelumnya dapat diketahui bahwa strategi pengembangan kompetensi pustakawan di Dinas Perpustakaan dan Kearsipan Kabupaten Gunung Kidul dibagi menjadi dua yaitu pengembangan secara formal dan informal. Pengembangan secara formal berupa: diklat, bimtek, worksop, seminar, organisasi profesi, lomba pustakawan berprestasi dan wilayah binaan untuk pustakawan. Sedangkan pengembangan kompetensi pustakawan secara informal meliputi : menjadi narasumber atau pembicara, koordinasi sesama pustakawan, networking, dan relationship.

Selain kegiatan-kegiatan tersebut di atas, terdapat faktor pendukung dalam pelaksanaan pengembangan kompetensi pustakawan diantaranya: motivasi dalam diri pustakawan itu sendiri serta dukungan penuh dari pihak dinas dan Kepala Dinas Perpustakaan dan Kearsipan Kabupaten Gunung Kidul. Di sisi lain dalam proses pengembangan kompetensi pustakawan terdapat faktor penghambat yang perlu menjadi perhatian khusus yakni terkait dengan anggaran dana untuk pengembangan kompetensi pustakawan dan pembatasan kuota dalam sebuah kegiatan. Pengembangan kompetensi merupakan sebuah tuntutan bagi pustakawan guna mengoptimalkan sumber daya yang dimiliki. Pelaksanaan pengembangan kompetensi ini tidak dilakukan hanya sekali waktu, namun perlu dilakukan secara terus menerus dan berkelanjutan. Hal ini bertujuan untuk meningkatkan layanan perpustakaan dan mewujudkan visi misi yang dimiliki oleh Dinas Perpustakaan dan Kearsipan Kabupaten Gunung Kidul. 


\section{DAFTAR PUSTAKA}

Badan Pengembangan dan Pembinaan Bahasa. 2018. Kamus Besar Bahasa Indonesia. Jakarta: Kementrian Pendidikan dan Kebudayaan Republik Indonesia.

Indonesia. 2007. Undang-Undang Nomor 43 Tahun 2007

Indonesia. 2014. Peraturan Pemerintah No 24 Tahun 2014

Lasa. 2017. Manajemen Sumber Daya Manusia Perpustakaan. Yogyakarta: Ombak.

Kadarisman, M. 2013. Manajemen Pengembangan Sumber Daya Manusia. Jakarta: Rajawali.

Qalyubi, Syihabuddin, dkk. 2007. Dasar-Dasar Ilmu Perpustakaan dan Informasi.Yogyakarta: Jurusan Ilmu Perpustakaan dan Informasi Fakultas Adab dan Ilmu Budaya UIN Sunan Kalijaga.

Safaria, Triantoro. 2004. Kepemimpinan. Yogyakarta: Graha Ilmu.

Sugiyono. 2018. Metode Penelitian Kuantitatif, Kualitatif, dan R\&D. Bandung: Alfabeta.

Suwarno, Wiji. 2011. Perpustakaan \& Buku: Wacana Penulisan \& Penerbitan. Jogjakarta: Ar-Ruzz Media. 